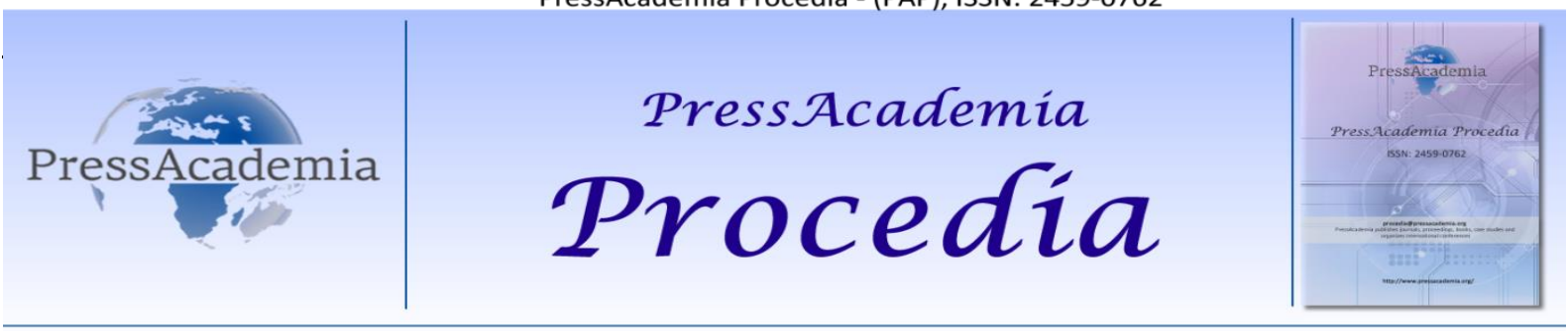

Global Business Research Congress (GBRC), May 24-25, 2017, Istanbul, Turkey.

\title{
LEAN MANAGEMENT APPLICATION AND PROCESS DESIGN AT RESEARCH HOSPITAL OUTPATIENT CLINICS
}

\author{
DOI: 10.17261/Pressacademia.2017.417 \\ PAP-GBRC-V.3-2017(32)-p.323-336
}

\author{
Hatice Camgoz Akdag ${ }^{1}$, Mustafa Orcun Oduncu ${ }^{2}$, Gorkem Saglam ${ }^{3}$, Nuh Zafer Canturk ${ }^{4}$ \\ ${ }^{1}$ Istanbul Teknik Üniversitesi, İşletme Fakültesi, İşletme Mühendisliği Bölümü, Istanbul, Türkiye. camgozakdag@itu.edu.tr \\ ${ }^{2}$ Istanbul Teknik Üniversitesi, İşletme Fakültesi, İşletme Mühendisliği Bölümü, Istanbul, Türkiye. orcunoduncu@gmail.com \\ ${ }^{3}$ Istanbul Teknik Üniversitesi, İşletme Fakültesi, İsletme Mühendisliği Bölümü, Istanbul, Türkiye. gorkemsaglam@yahoo.com \\ ${ }^{4}$ Kocaeli Üniversitesi Araştırma ve Uygulama Hastanesi, Kocaeli, Türkiye. canturkz@yahoo.com
}

\section{To cite this document}

H. Camgoz Akdag, M. O. Oduncu, G. Saglam and N. Z. Canturk (2017). Lean management application and process design at research

hospital outpatient clinics. PressAcademia Procedia (PAP), V.3, p.323-336

Permemant link to this document: http://doi.org/10.17261/Pressacademia.2017.417

Copyright: Published by PressAcademia and limited licenced re-use rights only.

\begin{abstract}
Responding customers' demands quickly and providing the superior quality for them is vital for companies to keep in their business and raise their market share in today's competing work environment. It is necessary to focus on customers' needs and demands in service sector such as hospitals. Main customers in hospitals are patients so that waiting in queues is the main problem for this specific environment. Anticipations are mostly non-value added activities and cause waste of money and time. Non-value added activities and insufficient usage of valuable devices must be disposed of the system. Lean management techniques is one of the most significant technique, help to lower wastes and decrease patients wait time. Lean management also known as Toyota production system and there are various techniques of it. Value stream mapping (VSM), job standardization and $5 \mathrm{~S}$ are most applied ones in service sector. The thesis shows applied lean management techniques could increase efficiency on material usage and decrease patients wait time in hospitals. VSM leads to determine the wastes, job standardization leads to specify the work rules for every worker and $5 \mathrm{~S}$ leads to organize the work environment; these 3 approaches has been evaluated during thesis. The Arena simulation depends on the determined flow of patients in the research hospital. Non-value added and unnecessary activities, which cause patients to wait has been determined, simulated within different scenarios and eliminated by using Arena.
\end{abstract}

Keywords: Lean Hospital, 5S, Value Stream Map, Simulation, Outpatient Clinics.

JEL Codes: I19, L15, M11

\section{ARAŞTIRMA HASTANESI POLIKLINIKLERINDE YALIN YÖNETIM UYGULAMA VE SÜREÇ TASARIMI}

\section{ÖZET}

Çalışmanın amacı seçilen araştırma hastanesinin poliklinik süreçlerinde kalite yönetim teknikleri kullanılarak, sistemin iyileştirilmesidir. Değer akışı haritalandırma, iş standartlaştırma ve $5 S$ yöntemleri uygulanarak israfların kolayca görülmesini sağlamak için değer akış haritalandırma yapılmıştır. Rastgele seçilen hastanın/hasta yakınının seçimi sabit proje ekibi tarafından pareto analizi kullanılarak belirlenmiştir. Seçilen hasta/hasta yakınına ait mevcut akış haritası çizilmiş ve bu akışta katma değer yaratmayan faaliyetler belirlenmiştir. Araştırma hastanesinde genel cerrahi polikliniği hastalarının sistem içindeki akışı belirlenmiş ve bu akışa göre Arena programında benzetimi yapılmıştır. Arena programı ile sistemde katma değer yaratmayan ve hastaların beklemesine sebep olan faaliyetler belirlenmiş ve yalın yönetim teknikleri ışığında çeşitli öneri senaryoları benzetime dâhil edilmiştir. Dört farklı iyileşme önerilmiştir. Sonuç olarak dört farklı iyileşme önerisinde de hastaların bekleme sürelerinde düşüş gerçekleşmiş olup çalışan sayısında azalma sağlayan öneriler de maliyetin düşmesini sağlamıştır. Hastane yöneticileri kendilerine uygun buldukları, uygulayabileceklerini düşündükleri öneri ve önerileri uygulamaya koyarak hastaların sistem içinde daha az beklemesini sağlayarak kalite artımında bulunabilirler.

Anahtar Kelimeler: Yalın Hastane, 5S, Değer Akış Haritalandırma, Benzetim, Genel Cerrahi Polikliniği JEL Codes: I19, L15, M11 


\section{GíRiş}

Son zamanlarda hizmet sektörünün büyümesi sağlık sektöründe de büyümeye sebep olmuş, sağlık sektörünün hizmet sektöründeki payını arttırmıştır. Artan teknolojik gelişmeler ile sağlık hizmetlerindeki uygulamalar değişmiş, hizmetin kalitesi ve hastaların beklentileri de buna bağlı olarak artmıştır. Ancak bu teknolojik gelişmeler maliyetli olması nedeni ile hastane harcamalarını arttırmıştır. Bu da ülke çapında sağlık sisteminin gözden geçirilmesine ve düşük maliyetli hizmet sunulması için yollar aranmasına neden olmuştur.

Sağlık hizmetleri denilince ilk akla gelen yer hastanelerdir. Hastaneleri sağlık hizmeti veren bir işletme olarak düşünürsek ve harcanan kaynak maliyetlerini göz önüne alırsak sermaye yoğun işletmeler kategorisine girer. Bu kaynak maliyetleri arasında insan kaynağı maliyeti, bina ve tıbbi donanım maliyetleri, ilaç ve tıbbi malzemeleri yer almaktadır (Yıldız ve Yalman, 2015). Sağlık hizmetlerine ayrılan bütçenin önemli bir kısmının hastanelerde tüketilmesi büyük bir problem oluşturmaktadır. Hastanelerden kaynaklanan sorunlar uzun zamandır baş göstermektedir ve bu sorunların çözümü ancak ülkedeki sağlık sistemi ele alındığında çözülebilecektir (Sur, 2008).

Diğer hizmet sektörlerine göre hastanelerde kullanılan cihaz ve donanımlar teknoloji olarak çok daha karmaşık bir haldedir. Bu nedenle hastanelerde teknolojik araç ve sistemlerin yönetimi çok önemlidir. Özellikle hastanelerin yüksek risk taşıyan; acil servis, ameliyathane ve radyoloji gibi bölümlerinde kullanılan cihazlarda kullanım hataları ve cihaz arızaları sık sık meydana gelmektedir (Yıldız ve Yalman, 2015). Buna bağlı gereksiz maliyetler, muayene kalitesinde azalmalar, hasta memnuniyetinde düşüşler meydana gelmektedir.

Sağlık bakanlığı hekim seçme hakkı gibi projelerle daha bireysel sağlık hizmeti sunarken, bir yandan da hastanelerdeki çalışan performans, verimlilik ve hasta tatminini arttırmak istemektedir. Ancak; bütçeyi aşan maliyetler, son zamanlarda artan teşhis ve ameliyat hataları, hastanın boşa harcanan vakti ve bürokratik verimsizlikler gibi sebepler buna müsaade etmemektedir. Kalite kapsamında yapılacak olan çalışmalar ile hem bu sorunlar ortadan kaldırabilecek hem de hastaların süreçte daha az beklemesine ve çok daha fazla hastanın daha düşük maliyetle tedavi olmasını sağlayacaktır.

Bu çalışmanın amacı seçilen araştırma hastanesinin poliklinik süreçlerinde kalite yönetim teknikleri kullanılarak, sistemin iyileştirilmesidir. Erişilecek çıktılar:

- Mevcut süreç akış şemalarının çıkartılarak katma değer yaratmayan faaliyetlerin belirlenmesi

- Katma değer yaratmayan faaliyetlerin, zorunlu faaliyetler ve kaçınılabilir faaliyetler olarak sınıflandırılması

- $\quad$ Sistemde bulunan ve katma değer yaratmayan faaliyetlerden arındırılması için önerilerin geliştirilmesi

- $\quad$ Oluşturulan önerilerin hastane yönetimi ile konuşularak uygulanabilir önerilerin belirlenmesi

\section{LITERATÜR INCELEMESI}

1974 petrol krizinden sonra, özellikle batı dünyasının üretim alanında uygulamaya başladığı toplam kalite yönetimi 'Japon Yönetim Felsefesinin' bir alt sistemi olarak görülmektedir. Çalışanların ve yöneticilerin rollerindeki önemli değişiklikleri vurgulayan ve bu açıdan klasik yaklaşımdan ayrılan toplam kalite yönetimi; "Müşterilerin ihtiyaçlarını en ekonomik düzeyde karşılamak amacı ile işletmenin değişik bölümlerinin; kalitenin yaratılması, yaşatılması ve geliştirilmesi yolundaki çabalarını birleştirip koordine eden etkili bir yöntemdir" (Fliehman, Auld,1993; 53).

Kalite çemberinin içine aldığı kanban ve andon sistemleri ile 'Japon Yönetim Felsefesi' tam zamanında üretim olarakta bilinir. Bu üretim sisteminin başarısı üretimin özgün ve verimlilik odaklı olmasındandır (Zerenler ve İraz, 2006). Zerenler ve İraz makalelerinde tam zamanında üretimi "Tam Zamanında Üretim (TZÜ) Sistemi; üretim için gerekli olan stokların gerektiği anda ihtiyaç noktasında bulunmasını sağlayan ve sıfır stoku hedefleyen bir stok yönetim sistemidir." şeklinde tanımlamışlardır (Zerenler ve İraz, 2006).

Japonca kai (değişim) ve zen (iyi) kelimelerinden oluşan 'Kaizen' de, toplam kalite yönetiminin önemli bir parçasını oluşturmaktadır. Sürekli yenilik ile gelişimi, gelişim ile de mükemmelliğe ulaşmayı hedeflemektir (Zerenler ve İraz, 2006).

Egemen anlayışın 'sürekli iyileştirme' ve 'rekabetçi yapılanma' olduğu toplam kalite yönetiminde, 'yalın düşünce'nin önemli etkisi bulunmaktadır (Tikici ve Derin, 2006).

\subsection{Yalın Yönetim Felsefesi ve Kavramları}

Yalın yönetim kavramından önce yalın üretimin ihtiyaç duyulmayan her türlü süreç ve elemandan kurtulmak olduğunu bilmek gerekmektedir. Daha da basitleştirirsek, süreçte kullanılan gereksiz, ihtiyaç fazlası kaynakları azaltarak, daha çok çıktı elde etmektir. 


\subsubsection{Yalın Düşünce}

Yalın düşüncenin temel hedefi süreçlerdeki katma değerli ve katma değerli olmayan işlemleri belirleyip, katma değeri olmayan süreçleri azaltarak israfı yok etmektir.

Yalın düşünce; "yalın bir üretim sistemine, yalın bir şirkete, yalın bir değer zincirine ulaşma" düşüncesidir. Yalın düşüncenin amacı, yönetimin ilgi merkezini değiştirerek, "değerin" "israf "tan elimine edilmesini sağlamak, organizasyonlar, teknolojiler sabit kıymetler yerine, kaynakların üretimini ve ürünü etkileyecek çalışmalara odaklanmak ve israflardan arınarak zenginliği yakalamaktı (Tikici ve Derin, 2006).

\subsubsection{Yalın Üretim}

Yalın üretim, "en az kaynakla, en kısa zamanda, en ucuz ve hatasız üretimi, müşteri talebine de birebir uyabilecek/yanıt verebilecek şekilde, en az israfla (daha doğrusu israfsız), ve nihayet tüm üretim faktörlerini en esnek şekilde kullanıp, potansiyellerinin tümünden yararlanarak nasıl gerçekleştiririz" arayışııın sonucudur ( Yıldız \& Yalman, 2015). Yalın üretimin en önemli stratejisi süreçte sürekli iyileştirme yapmaktır. Bu iyileştirmeyi de akışı hızlandırıp, sürecin kısalmasını sağlayarak veya maliyeti azaltırken kalite ve performansı arttırarak sağlamaktadır.

\subsubsection{S}

Baş harfleri ' $S$ ' olan 5 Japonca kelimeden oluşan $5 S$ işyerlerinde kaliteli bir çalışma ortamı sunan sistematik bir yaklaşımdır (Artıısık, 2008). Bu Japonca kelimeler:

- $\quad$ Seiri (Ayıkla): Gerekli olanları gereksiz olanlardan ayırma işlemidir.

- $\quad$ Seiton (Düzenle): Gerekli olanların yerleştirilmesindeki düzendir. İstenilen malzemeye, gerektiği zamanda, gerektiği miktarda ulaşılmasını amaçlar. Zamandan israf edilmesini büyük ölçüde önler.

- $\quad$ Seiso (Temizle): Sistemde arıza, kaza ve kalite düşüşünü önlemek amaçlı temizleme, yıkama safhasıdır.

- $\quad$ Seiketsu (Standartlaştırma): Illk üç S'in sürekliliğini sağlamak için işlerin belirli standartlarda yapılmasıdır.

- $\quad$ Shitsuke (Disiplin): Ilk dört S'in başarılı bir şekilde ilerlemesi için disiplinin sağlanmasıdır. Yapılması gereken her şeyi istenildiği şekilde ve sürekli yapılmasını sağlar.

$5 S^{\prime}$ in uygulanması ile sıfır hata hedeflenmektedir. Düzenleme ve sınıflandırma yanlış alet kullanımını önlerken, kullanılacak aletlerin temizliği işlem hatalarını önler. Hataların yok edilmesi parça israfının oluşmasını da engeller. Ayrıca makine de oluşacak her hangi bir hatadan kaynaklı gecikme ve buna bağlı zaman israfı ortadan kaldırılır. Aletlerin belirli alanlarda bulunması ve düzenli temizlik ile iş kazalarının önüne geçilmiş olup güvenli bir çalışma ortamı oluşturulur. $5 S^{\prime}$ in üretici, müşteri ve çalışana yararını sıralayacak olursak;

Üreticiye yararı: Azalan makine arızaları, artan verimlilik, azalan israf, artan iş güvenliği ve artan kar (Ergoterapi ve Rehabilitasyon 2014 Mayıs; 2, 2: 74-75).

Müşteriye yararı: Tam zamanında performans, artan dağıtım performansı, düşen fiyat ve üretici - müşteri ilişkisinin iyileşmesi (Ergoterapi ve Rehabilitasyon 2014 Mayıs; 2, 2: 74-75).

Çalışana yararı: Fikir üretme ve bakış açılarını genişletme imkânının sağlanması, çalışma motivasyonun artması ve zamanın etkin kullanılması (Ergoterapi ve Rehabilitasyon 2014 Mayıs; 2, 2: 74-75).

\subsection{3 . KANBAN Sistemi}

KANBAN sistemi, tam zamanında üretim sisteminde önemli bir rol oynayan yeni bir felsefedir. Kanban, bir ürünün üretim ve montaj hattının her aşamasında ve tamamlanma yolundaki ayrıntıları içeren genellikle plastik bir karttır. Çok aşamalı bir üretim ve envanter kontrol sistemi olan Kanban, üretim süresini azaltırken üretim hacmi ve kapasite kullanımını kolaylaştıır. Kanban kartında; kullanıldığı yer, parça numarası, parça adı, parça tanımı ve Kanban numarası yer alır (Kumar ve Panneerselvam, 2007).

Kullanıldıkları yere ve amaca göre iki çeşit kanban vardır. Bunlar çekme kanbanı ve üretim kanbanıdır. Çekme kanbanı bir sonraki sürecin bir önceki süreçten çekmek istediği parça türünü, miktarını ve kalitesini belirler. Üretim kanbanı ise o anki süreçte üretilmesi gereken ürünün türünü ve miktarını belirler. Bu iki kanbanın yer aldığı sistemlere süper market çekme sistemi de denilmektedir. 


\subsection{Yalın Hastane Uygulamaları}

Bolu'daki hastaneler için uygulanması planlanan Yalın Yönetim kavramı şu şekilde tanımlanmıştır; sunulan sağlık hizmetlerinin daha kaliteli, güvenli ve verimli; ekip anlayışı içerisinde; hizmet verenlerle, hizmet alanların memnuniyetini artırmaya yönelik iyileştirme faaliyetlerinde bulunmaktır. Verdiğimiz sağlık hizmetlerinin her açıdan daha iyi bir noktaya taşınması ve kalitesinin arttırılması gerekmektedir. Yalın Düşüncenin temel amacı, süreçlerdeki israfları yok ederek sağlık hizmetinin hastaya ulaşana kadar geçirdiği toplam süreyi kısaltmaktır. Sürenin kısalması ile hasta memnuniyeti ve kalite artacak, beklemeler ve stoklar azalacaktır. Sonuç olarak maliyetler düşecek ve daha kolay yönetilebilir bir sağlık sistemi kurgulanmış olacak, böylelikle kurumun gelişimi sağlam temeller üzerine oturacaktır. Bunun anahtarı da yalın hastane gibi süreçleri kısaltan sistemler kurmaktır. Kurumda yalın hastane mantığını oluşturmak ve yerleştirmek, gelişimini ve sürekliliği sağlayarak doğru planlama ile afiliye olan hastanelerimizdeki yalın hastane sistemi kurum kültürü oluşturulmasıyla yeni bir kurum kültürü modellenin oluşmasına katkı sağlamaktır. (http://www.tkhk.gov.tr/DB/8/2946_yalin-hastane-sistem).

Sağlık işletmelerinde yalın düşünce zorluklar ve darboğazların çözümünde, yalın araçları kullanmak için personeli güçlendirir ve işlerini zenginleştirmek için bir fırsat sunar. Bunun yanı sıra, sağlık işletmelerinin maliyetlerini azaltarak ve kapasitelerini geliştirerek iyileştirmeleri kolaylaştııı. Ayrıca yalınlık, bekleme zamanlarını ve iş süreçlerini kısaltarak ve hasta akışını iyileştirerek, hasta güvenliğini ve kalitesini yükseltir ve bir hastanın tedavisi yoluyla israfları azaltarak veya ortadan kaldırarak hasta memnuniyetini artırır (Naraghi and Ravipati, 2009).

Sağlık sistemi sağlıkta kalitede artan beklentiler de dâhil olmak üzere, hızla değişen çalışma ortamında, zorluklar ve fırsatlar ile karşı karşıya kalmaktadır (Shazali, 2013). Yalın kavramı aslında, organizasyonel performans ve tatmin edici müşterilerini artırırken, yüksek kaliteli ürün ve hizmetler sunmak için otomotiv sektöründe gelişme göstermiştir (Marshall, 2006). Ancak, bazı kuruluşlar sağlık sektörü için bu kavramları benimsemeye başlamıştır. Rexhepi ve Shrestha (2011), sağlık sektörünün yalın uygulamalara ihtiyacı olduğunu vurgulamıştır. Bunun, yalnızca hastanelerde geçerli olmadığını, aynı zamanda özel kliniklerde veya huzurevinde de uygulanabileceğini ifade etmişlerdir.

Yalınlığın, süreçlerde israfı belirlemek ve ortadan kaldırmak için etkili bir araç olduğu ifade edilmiştir (Hagg ve WorkmanGerman, 2007). Sağlık hizmetlerinde yalın uygulamanın amacı ve faydası, kurum içindeki esnekliği, kaliteyi ve hızı inşa ederken; gereksiz taşımaları ve bekleme sürelerini yatııımlara odaklanmaz, ancak sağlık kuruluşlarına yüksek yatırımlar gerekmeksizin iyileşme sağlanması yolunda alternatif bir yöntem sunar (Bahensky, Roe ve Bolton, 2005).

\subsection{Benzetim ile Süreç Tasarımı}

Benzetim, fiziki şartlarda denenmesi zor, zaman alıcı ve pahalı olan karar problemleri davranışlarının bilgisayar ortamlarında istendiği kadar türetilmesi ve tekrarlanması işlemlerine verilen teknik isimdir. Bir sistemin benzetimi, sistemi temsil edebilecek bir model oluşturma ve gerçek hayattaki olayların bilgisayar ortamına aktarılması işlemidir.

Benzetim modelleri uzun vadede gerçek deneyimler ve gerçek yanılmalar ile ulaşılabilecek tecrübenin, bilgisayar tarafından canlandırılan tamamen güvenli bir ortamda kazanılmasını mümkün kılmaktadır. (Harrel, Ghols, Bowden, 2000).

Bir sistemin benzetimi, sistemi temsil edebilecek bir model oluşturma ve gerçek hayattaki olayların bilgisayar ortamına aktarılması işlemidir. Benzetim ile bilgisayar ortamlarında, fiziki şartlarda denenmesi zor, zaman alıı ve pahalı olan karar problemleri davranışlarının istendiği kadar türetilmesi, tekrarlanması ve uygulayıcılara alternatif modeller arasından seçme şansı sağlanmaktadır(Anderson, Sweeney, Thomas, 2000). 


\subsection{4 .Arena Programı ile Benzetim Uygulamaları}

Rockwell Arena, Rockwell Automation tarafından geliştirilen bir benzetim ve otomasyon yazılımı olmakla birlikte SIMAN benzetim dilini kullanmaktadır. Arena bir şirketin üretim sürecini simüle etmek ve performansını ölçmek için kullanıldığı gibi akademik amaçlarla da kullanılabilir. Sürecin simüle edilmesiyle birlikte, sistemin gerçek hayatta yapacaklarını önceden deneyerek zaman ve kaynak tasarrufu edilmiş olur.

Arena istatistiksel verilerin alınması için de kullanışlıdır. Kuyruklardaki ortalama varlık sayısı, kuyruktaki maksimum ve minimum varlık sayısı, kaynağın kullanımda olduğu süreler gibi değerler elde edilebilir. Ayrıca üretimde hatalar, makinelerde arıza, yemek arası, molalar, belirli mesai saatleri belirlenerek model gerçekçi hale getirilir. Arena benzetim programını kişi, kurum ve kullanım amaçlarına göre aşağıdaki şekilde sınıflandırabiliriz. (Yıldız, 2010)

Evans ve diğerleri Rockwell Arena Simülasyon yazılımını kullanarak bir acil servisteki 13 hasta kategorisini değerlendirmiş, benzetim koşumundaki belirli saat dilimlerini göz önünde bulundurarak, vardiyalardaki hemşire sayıları ile teknisyen ve doktorların vardiyalarını farklı alternatifler ile çizelgelemiş ve hastaların acil serviste kalma sürelerini kısaltmışlardır. Komashie, Londra'daki bir acil serviste gerçekleştirdiği çalışmasında kaynakların (doktorlar, hemşireler ve yatak sayıları vb.) anahtar performans ölçütleri (bekleme süreleri, hasta kuyruk ve akış sistemleri) üzerindeki etkisini belirlemeye çalışmıştır. Çalışmada Rockwell Arena benzetim yazılımı kullanılmış, hastaların tıbbi durumlarına göre doktorlar ve hemşireler tarafından sunulan acil bakım/tedavi hizmetlerinin süreleri model değişkenleri olarak değerlendirilmiş ve farklı alternatifler sınanmıştır. Hastaların gelişler arası sürelerine ait olasılık dağılımları haftanın her günü için ayrı ayrı değerlendirilerek modele aktarılmış, bunun için ve diğer hizmet süreleri için gerekli verileracil servis kayıtları, personel ile mülakatlar ve acil servis gözlemleri ile elde edilmiştir. Bununla birlikte çalışma, benzetim yöntemi açışından uygun hazırlanmış olmakla birlikte triaj kategorileri, laboratuar işlemleri gibi bazı noktaları modele aktarmakta yetersiz kalmıştır. Modelde alternatifler değerlendirildiğinde hasta bekleme sürelerinin en aza indirildiği senaryonun, yüksek bir hasta yatak kapasitesine sahip olunup sistemde herhangi bir blokaj olmaksızın bütün hastaların kabul edildiği bir yapı ile elde edilen senaryo olduğu gösterilmiştir. (Yalçın, 2008)

\subsubsection{Yalın Üretim Sistemlerinin Benzetim ile Modellenmesi}

Langabeer'e (2009) göre yalın çalışmaların sağlık sektörüne uygunluğu sorusu birçok doktor ve yönetici için tartışma konusudur. Çalışmada, hastanelerde iki kalite iyileştirme yöntemi olan yalın ve altı sigma metotlarını kullanmıştır.

Dickson ve arkadaşları (2009) çalışmalarını, dört acil serviste uygulamışlardır. íki akademik ve iki kamu hastanesinde, uygulama öncesi ve sonrası, hasta akışı, hizmeti, bekleme süresi, hasta memnuniyeti gibi ölçümler yapmışlardır. Tüm prosesleri DAH tekniği ile haritalandırmışlardır. Tüm acil servislerde hasta sayısı artmasına rağmen acil servislerin üçünde hasta bekleme süresini azaltmışlardır. Yalın değişimde, personelin aktif bir şekilde çalışmaya katıldıklarını gözlemlemişlerdir. Yalın prensiplerin, davranış değişiklikleri yaparak, hasta bakım sürelerini azaltarak, kurum kültürü oluşturduğunu gözlemlemişlerdir.

Yine Dickson arkadaşları (2009) bir diğer çalışmalarında, imalat sanayinde kullanılan yalın üretimin, DAH tekniği yardımıyla hizmet işletmelerinde de uygulanabileceğini göstermişlerdir. Bunun için bir acil serviste yalın prensipleri uygulamışlardır. Araştırmada; yalın eğitimi, AS gözlemi, hasta akış analizi, sürecin yeniden tasarımı, yeni süreç testi ve tüm uygulama olmak üzere altı adımlık süreci takip etmişlerdir. Hasta memnuniyetini, hasta başına gideri, acil serviste kalma uzunluğunu ve hasta yığınını kapsayan temel ve operasyonelsonuç ölçümlerini iki yıl için karşılaştırmışlardır. Karşılaştırmanın yapıldığı bir sonraki yılda hasta sayısının artışına rağmen, acil serviste bekleme zamanı azalmış ve hasta memnuniyeti, hasta başına belirlenmiş maliyeti artırmaksızın önemli bir şekilde artmıştır. Yalın düşünce, hastalara gösterilen değeri artırmıştır.

\section{VERI VE YÖNTEM}

Hastaneyi yalınlaştırmak için hastanedeki tüm çalışanların uygulayabileceği büyük bir değişim söz konusu olup, bu değişim ancak üst yönetimin desteği alınarak yapılabilecektir. Üst yönetimin desteği ile hastanede yapılacak olan gözlemler için izin almak kolaylaşacak, yalın düşünce felsefesinin hastane çalışanları tarafından benimsenmesi hızlanacaktır. Üst yönetimle ortaklaşa belirlenen ve yalın düşünce felsefesinin tekniklerine hâkim uzman kişiler ve hasta/hasta yakınına göre belirlenen ekipler kurulacaktır. Rastgele seçilen hasta/hasta yakına hizmet sunan her çalışanın aktif bir şekilde proje ekibinde yer alması ve bu iyileşme sürecine aktif bir şekilde katılması gerekmektedir.

Üst yönetimin de izni ile her hafta mümkün olduğunca farklı günler hastaneye gidilecektir. Rastgele seçilecek olan hastanın/hasta yakınının seçimi sabit proje ekibi tarafından pareto analizi kullanılarak belirlenecektir. Seçilen hasta/hasta yakınına ait mevcut akış haritası çizilir ve bu akışta katma değer yaratmayan faaliyetler belirlenir. Katma değer yaratmayan faaliyetleri daha net görebilmek için Arena simülasyon programında hastaneden alınan veriler ile hastanenin polikliniklerinin simülasyonu oluşturulacaktır. Bu simülasyon ile hastaların sistem içerinden en çok hangi faaliyetlerde bekleme yaptığı, hangi faaliyetlerin akışta katma değer yaratmadığı tespit edilmesini kolaylaştıracaktır. Katma değer yaratmayan bu faaliyetler 
sistemden çıkartıldı̆̆ında oluşacak durumun tekrar çizilmesi, arena programı ile tekrar simülasyonu çıkartılıp bu hedef yapıya ulaşıımak için gereken Kaizen faaliyetleri planlanır. Poliklinikler için hazırlanan bu çalışmada planlanan Kaizen faaliyetleri hasta randevu sisteminin düzenlenmesi, hastane otomasyon sisteminin yeniden kurulması, muayene odaları ve radyolojide $5 S^{\prime}$ in uygulanması ve kanban uygulanmasıdır. Bu çalışmada uygulanacak metotlar Şekil 1'de görülmektedir. Şekil $1^{\prime}$ 'de Kaizen faaliyetlerinin planlanması ve uygulanması alt işlemler şeklinde gösterilmiştir. Bu alt işleme ait faaliyetler Şekil 2'de detaylı bir şekilde yer almaktadır.

\section{Şekil 1: Çalışmada Kullanılacak Metodlar}

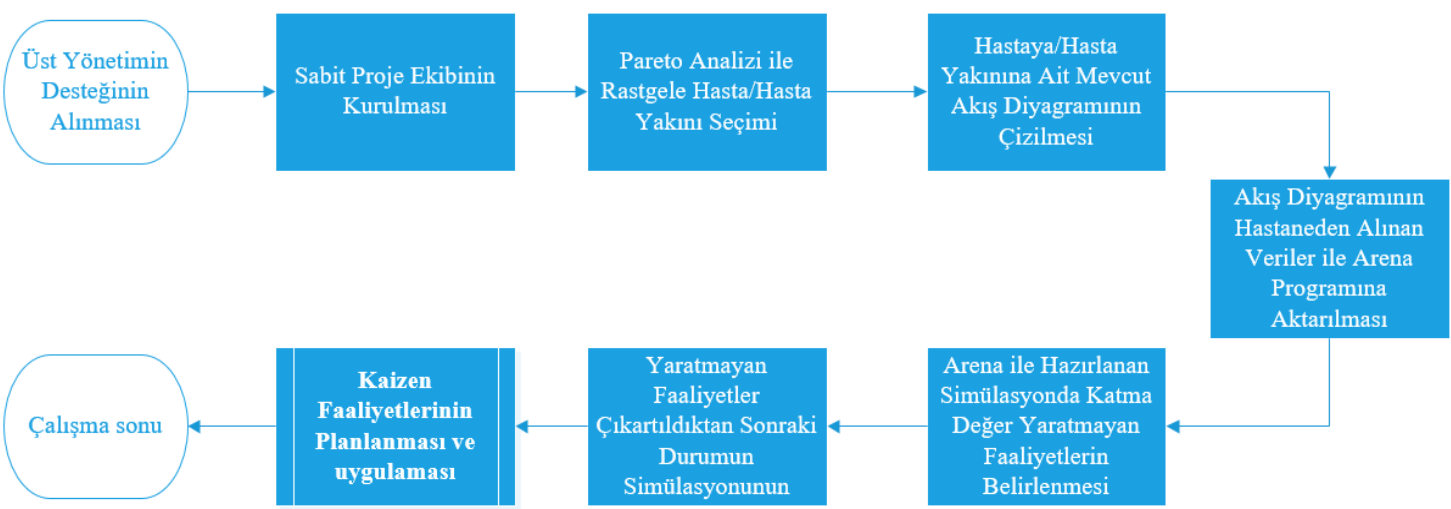

Şekil 2: Kaizen Faaliyetlerinin Detaylandırılması.

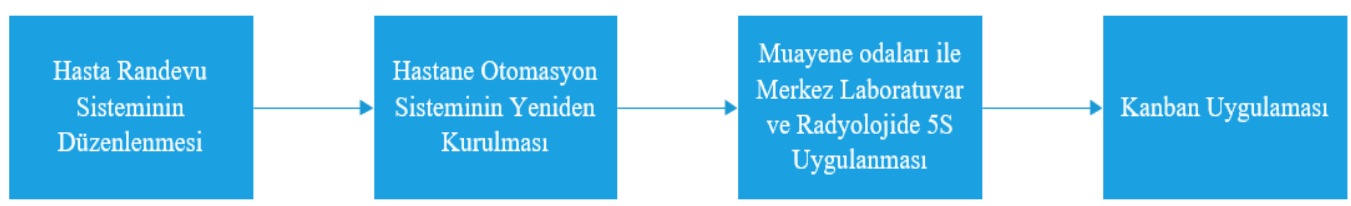

\section{BULGULAR VE TARTIŞMA}

\subsection{Mevcut Sürecin Belirlenmesi}

Araştırma hastanesinde 3 temel bölüm ve bunların altında toplamda 42 poliklinik bulunmaktadır. Kırk iki farklı poliklinik, kırk iki farkıı hasta/hasta yakını anlamına gelmektedir ve öncelikle iyileştirmenin yapılacağı grup pareto analizi ile belirlenmiştir. Şekil 3'de 3 temel bölüme gelen günlük ortalama hasta sayıları görülmektedir.

Şekil 3: Bölümlere Göre Günlük Ortalama Hasta Sayıları.

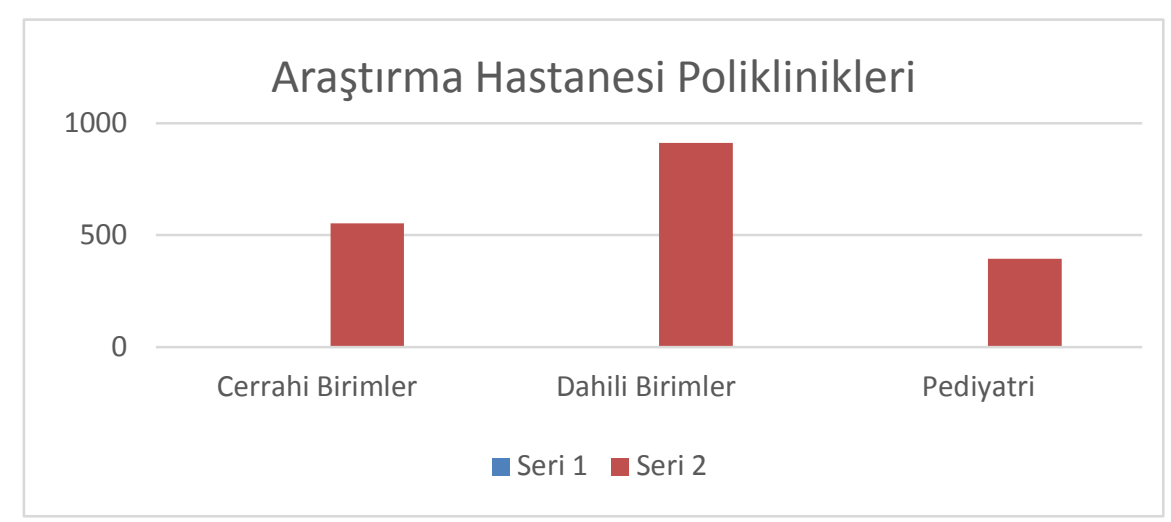


Şekilde de görüldüğü gibi hasta yoğunluğu dahili birimlerde diğer bölümlere göre çok daha fazla fakat; cerrahi birimlerde acil hasta ve ameliyatlardan dolayı çok daha fazla birikme olmaktadır. Cerrahi bölümün seçilmesi, hastalardan istenen röntgen, ultrason, MR ve laboratuvar gibi tetkikleri de içermesi açısından önemlidir ve bu bölümdeki iyileştirme aynı zamanda radyoloji ve merkez laboratuvarında da iyileştirme sağlayacaktır.

Cerrahi hastalarının tamamına yakınından laboratuvar ve radyoloji departmanına bağılı tetkikleri istenmektedir. Hastalar bu tetkiklerden birini bazen de birden fazlasında tetkik yaptırmak zorunda kalmaktadırlar. Çizelge 1'de hastalardan istenen tetkiklerin türlerine göre dağılım yer almaktadır.

Çizelge 1: Hastalardan İstenen Tetkikler

\begin{tabular}{|c|l|}
\hline Grup No & Yapılan İşlem ve İstenen Tetkikler \\
\hline 1 & Muayene \\
\hline 2 & Muayene + Röntgen \\
\hline 3 & Muayene + Laboratuvar \\
\hline 4 & Muayene + Ultrason \\
\hline 5 & Muayene + MR \\
\hline 6 & Muayene + Röntgen + Laboratuvar \\
\hline 7 & Muayene + Röntgen + Ultrason \\
\hline 8 & Muayene + Laboratuvar + Ultrason \\
\hline 9 & Muayene + Laboratuvar + MR \\
\hline 10 & Muayene + Ultrason + MR \\
\hline 11 & Muayene + Röntgen + Laboratuvar + Ultrason \\
\hline 12 & Muayene + Laboratuvar + Ultrason + MR \\
\hline
\end{tabular}

Bu 12 hasta grubunun işlem sürelerinin ortalama değerleri, gözlemlerimiz ve hastaneden alınan verilerle birleştirilerek hesaplandı. 12. Gruba dâhil olan hastaların bekleme süreleri hariç tutulsa bile, uzun süre sistemde kaldıkları tespit edilmiştir. Sistemde en uzun kalış süresine sahip 12. Grup cerrahi hastalarına yalın dönüşüm uygulanması müşteri memnuniyetini arttırmak için daha faydalı olacaktır.

\subsection{Neden-Sonuç Analizi}

Hastaların sistemde uzun süre bekleme yapması, giren hastanın sistemden uzun süre çıkmaması ve hasta muayenesinin düşük kalitede olmasının bazı temel sebepleri mevcuttur. Bunların en önemlileri insan, malzeme, hastane bilişim sistem ve çevredir. Hizmet sektörünün en önmelilerinden biri olan hastanelerde insan faktörü büyük sorunlara yol açmaktadır. Hasta, doktor, hemşire ve diğer kayıt çalışanlarını düşününce karmaşık bir hal alan insan faktörü muayene kalitesini etkileyen en önemli etmendir. Hastaların randevu saatlerinden çok önce veya çok sonra gelmesi ve bu nedenle çalışan kayıt çalışanları ve doktorun çalışmasına engel olmaları, çalışanların hem doktor kaydı hem de muayene odasına giren çıkan kontrolü yapması gibi birden fazla görevinin olması ve özellikle asistan doktorların yoğun çalışma saatleri hastanın uzun süre sistemde kalmasına ve muayene kalitesinin düşmesine sebep olmaktadır. Hasta kayıdından, hastanın yaptırması gereken tetkiklere kadar her şeyin yer aldığı HUY sistemi olarakta adlandırılan sistemin kullanıcı dostu olmaması, sistemin yavaş olması ve tetkik sonuçlarının kolaylıkla aktarılıp okunamadığı sistem hastanın bekleme süresini arttıran en büyük etken diyebiliriz. Tetkiklerde kullanılan malzemelerin etkin kullanılmaması, kullanım sırasında sıkça arızalanması ve bu kullanılan malzemelerin büyük maliyetli olmalarından dolayı yeni cihaz alımının zor olması hasta sürecini uzatmaktadır. Tüm bunlara ek olarak hastanın hastanede izleyeceği yolun iyi planlanmaması, hastanın muayeneden çok hastane içindeki koridorlarda vakit harcaması hem süreci uzatırken hem de hasta memnuniyetini düşürmektedir. Şekil 4'de hastanede oluşan uzun bekleme sürecini ve düşük muayene kalitesini özetleyen balık kılçığı(Ishikawa) diyagramı yer almaktadır. 
Şekil 4: Balık Kılçığı (Ishikawa) Diyagramı

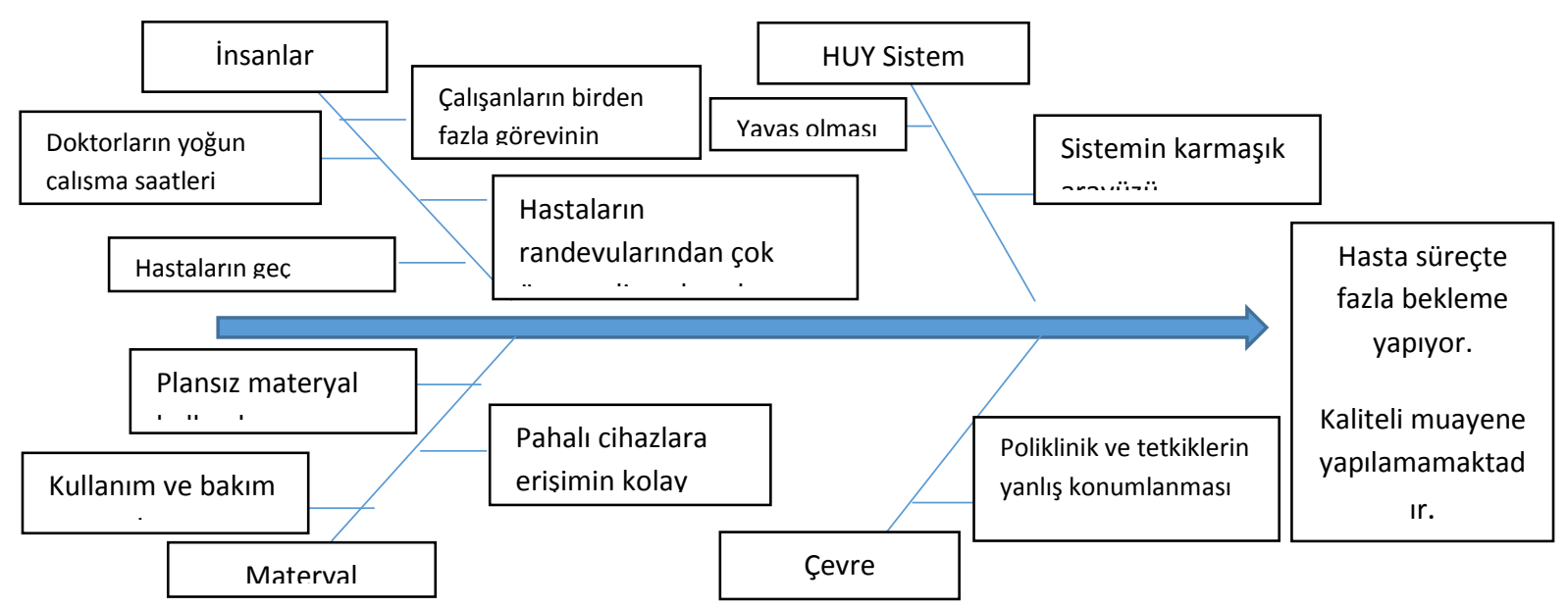

\subsection{Güncel Durumun Haritalandırılması}

Araştırma hastanesine gelen hastalar randevusuz, randevulu ve aciliyeti olan hastalar olarak üç gruba ayrılmaktadır. Randevusuz hastalar hastaneye geldiklerinde danışmada bulunan iki numaratörden o gün içerisinde muayene olmak istedikleri departmana dair numara almaktadırlar. Hastanenin özellikle pazartesi ve salı günleri yoğun olmasından dolayı randevusuz gelen hastaların birçoğu o gün içerisinde muayene olamamaktadır ve başka gün gelmek üzere randevu alabilmektedirler. Numaratörden numara alan randevusuz hastalar poliklinikler önünde bulunan hasta kayıtta kayıt yaptırarak doktoru beklerler. Randevulu ve aciliyeti olan hastalar da aynı randevusuz hastalar gibi hasta kayıtta kayıt yaptırarak doktoru beklemeye başlarlar. Aciliyeti olan hastalar ile birlikte numaratörden sıra alan ilk 5 randevusuz hastaya öncelik tanınarak muayene olması sağlanmaktadır. Muayene eden asistan doktor gerek gördüğü takdirde tetkik istemektedir ki araştırma hastanesi olduğu için hastaların yüzde doksanı gibi büyük bir çoğunluğundan tetkik isteniyor. Merkez laboratuvara bağlı kan ve idrar tahlilleri ile radyolojiye bağlı röntgen çekimi ve sonuçları muayene olunan gün halledilebilmektedir. Ancak radyoloji departmanına bağlı ultrason ve MR tetkikleri hastanın aciliyeti yoksa en iyi ihtimal iki ay sonra yapılabilmektedir. Hasta bu süreyi çok uzun bulursa daha erken tetkik yapılması için hastanede bulunan vezneye para yatırarak süreci kısaltmayı seçebilmektedir. Gerek iki ay sonra gerekse vezneye para yatırarak sürecin kısalması sonucunda alınan tetkik sonuçları asistan doktora kontrol ettirilir. Asistan doktor kontrol sonrasın da hastanın reçetesini yazıp çıkışını yaptığı gibi profesöre yönlendirme gereği de duyabilir. Hastalar profesöre yönlendirilir ancak; profesörler haftanın sadece bazı günleri muayene yaptıkları için hastaların randevu aldıkları tarih çok geç olabilmektedir. Randevu tarihini uygun bulan hastalar verilen tarihi beklerken, tarihi uygun bulmayan hastalar erken randevu alabilmek için vezneye para yatırmaları karşılığında daha erken muayene olabilmektedirler. Profesöre muayene olan hastalardan asistan doktorun gerekli görmediği bazı tetkikler veya tekrarlanması istenen tetkikler istenebilir. Asistan doktorun istediği tetkiklerde olduğu gibi merkez laboratuvarı ve röntgen tetkiklerinde zaman açısından sıkıntı olmazken radyolojiye bağlı diğer tetkikler uzun süreçler sonunda yapılabilir. Süreci kısaltmak isteyen hastalar vezneye para yatırarak kısaltarak tetkik sonuçlarına kısa sürede ulaşabilir ve profesör doktora kontrol ettirebilir. Profesör doktor tetkik sonuçlarını kontrol ettikten sonra hastanın reçetesini yazıp sistemden çıkmasını sağladığı gibi hastanın belirli aralıklarla tekrar gelmesi için süreci tekrara alabilir.

Şekil 5, 6, 7, 8 ve 9 hastaların izlediği yolların genel akış diyagramını göstermektedir. 
Şekil 5: Poliklinik Hasta Akış Diyagramı-1.

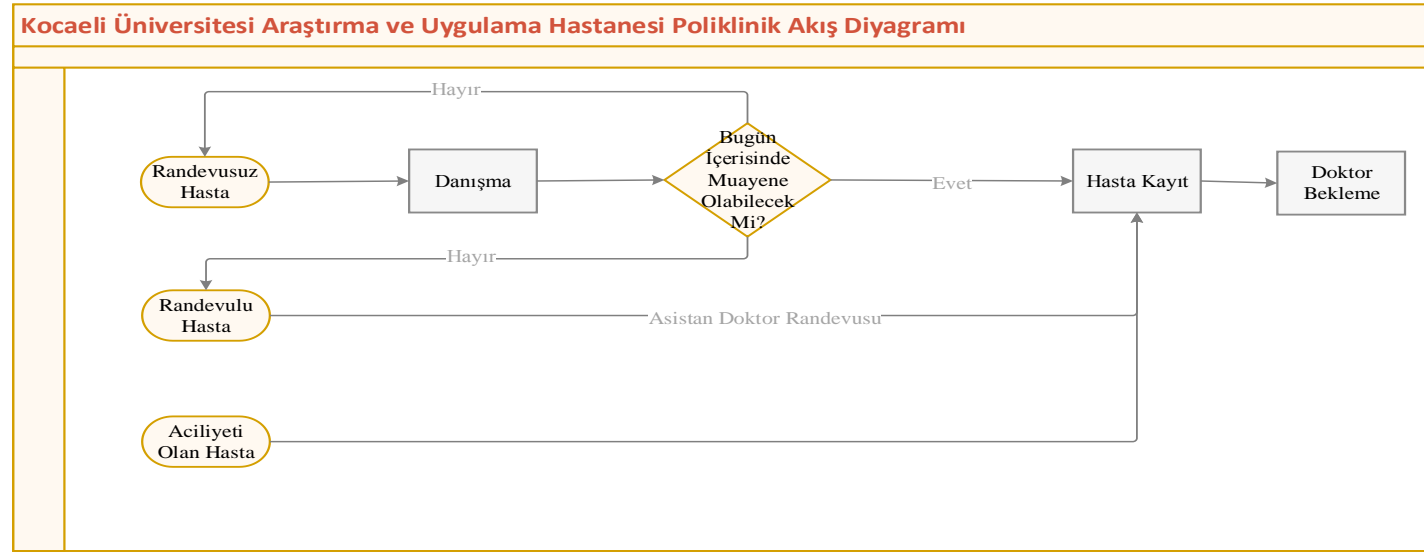

Şekil 6: Poliklinik Hasta Akış Diyagramı-2.

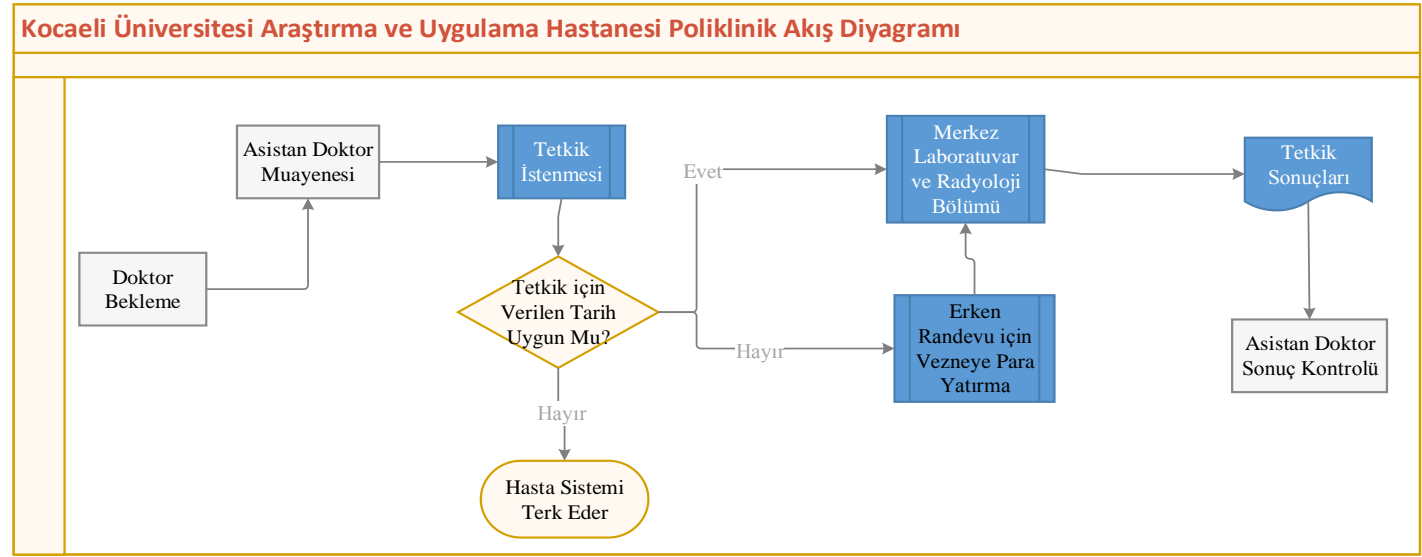

Şekil 7: Poliklinik Hasta Akış Diyagramı-3.

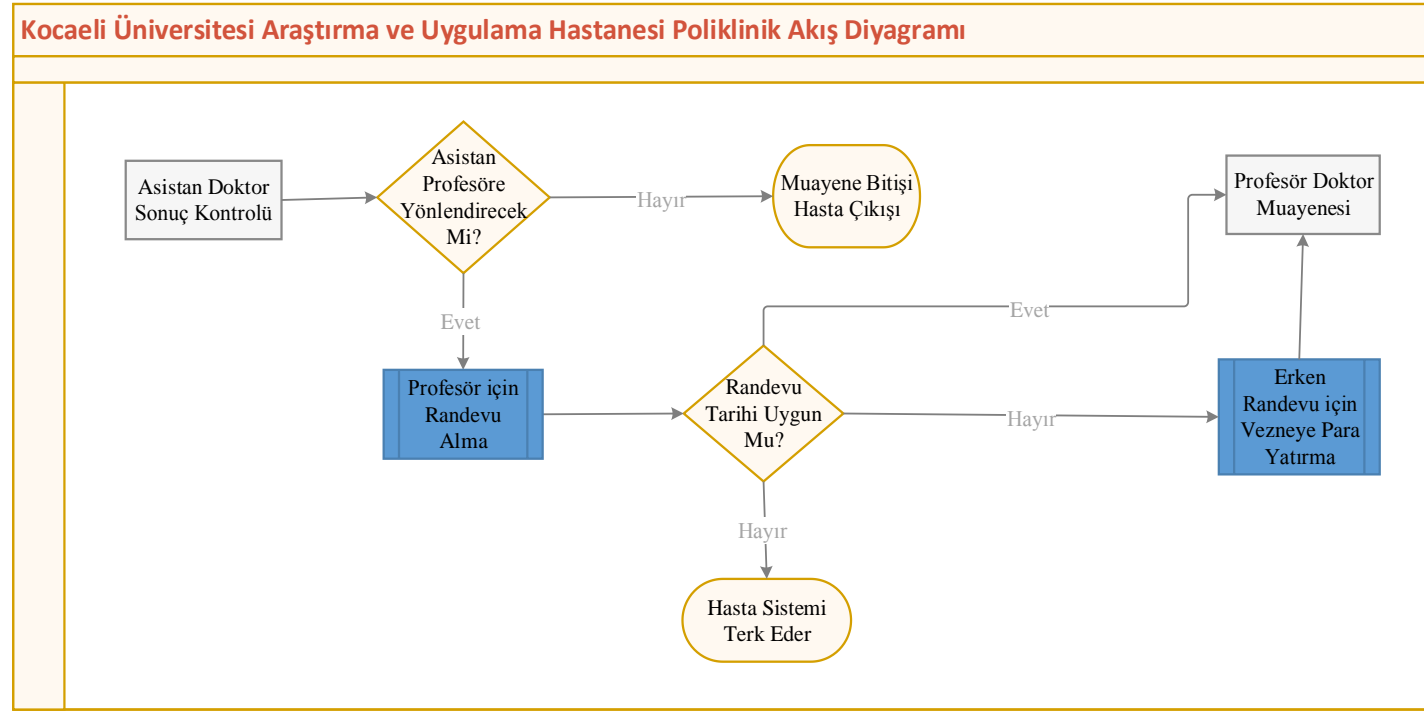


Şekil 8: Poliklinik Hasta Akış Diyagramı-4.

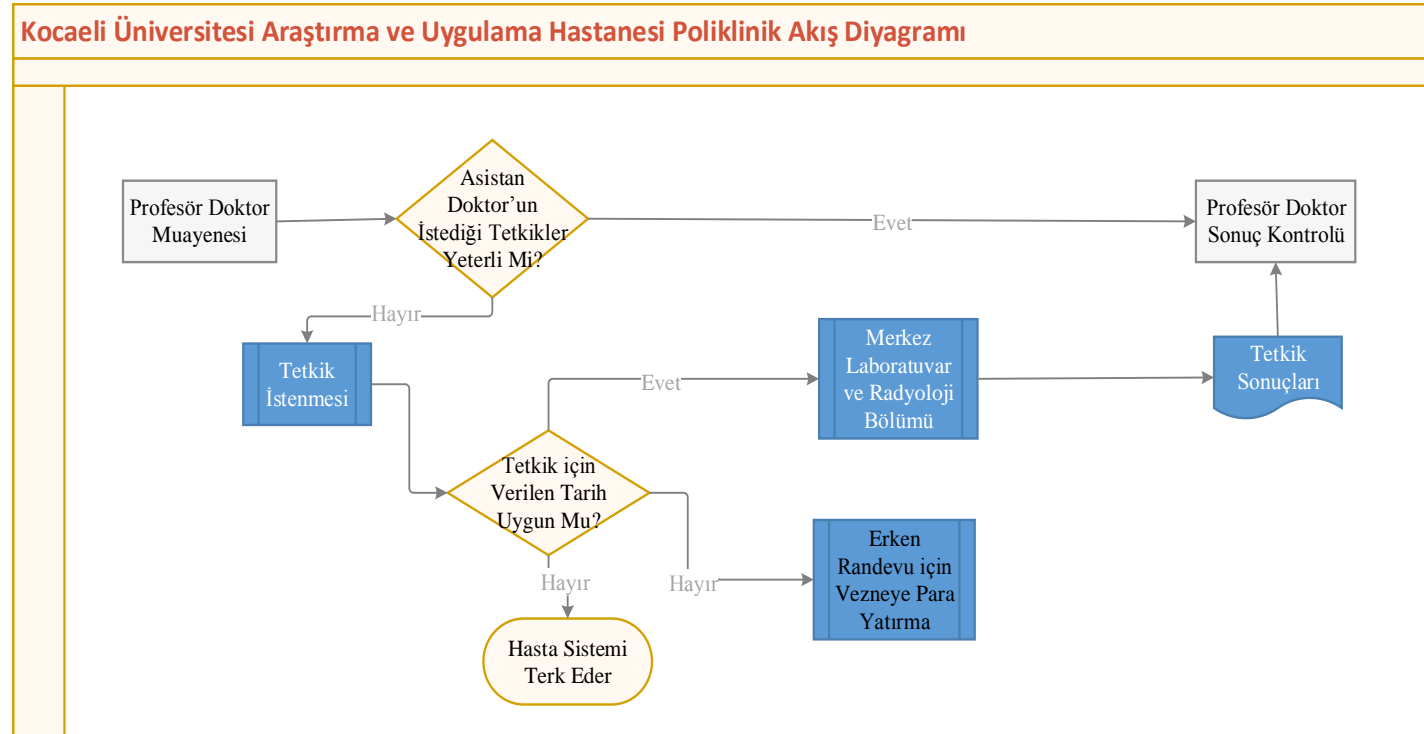

Şekil 9: Poliklinik Hasta Akış Diyagramı-5.

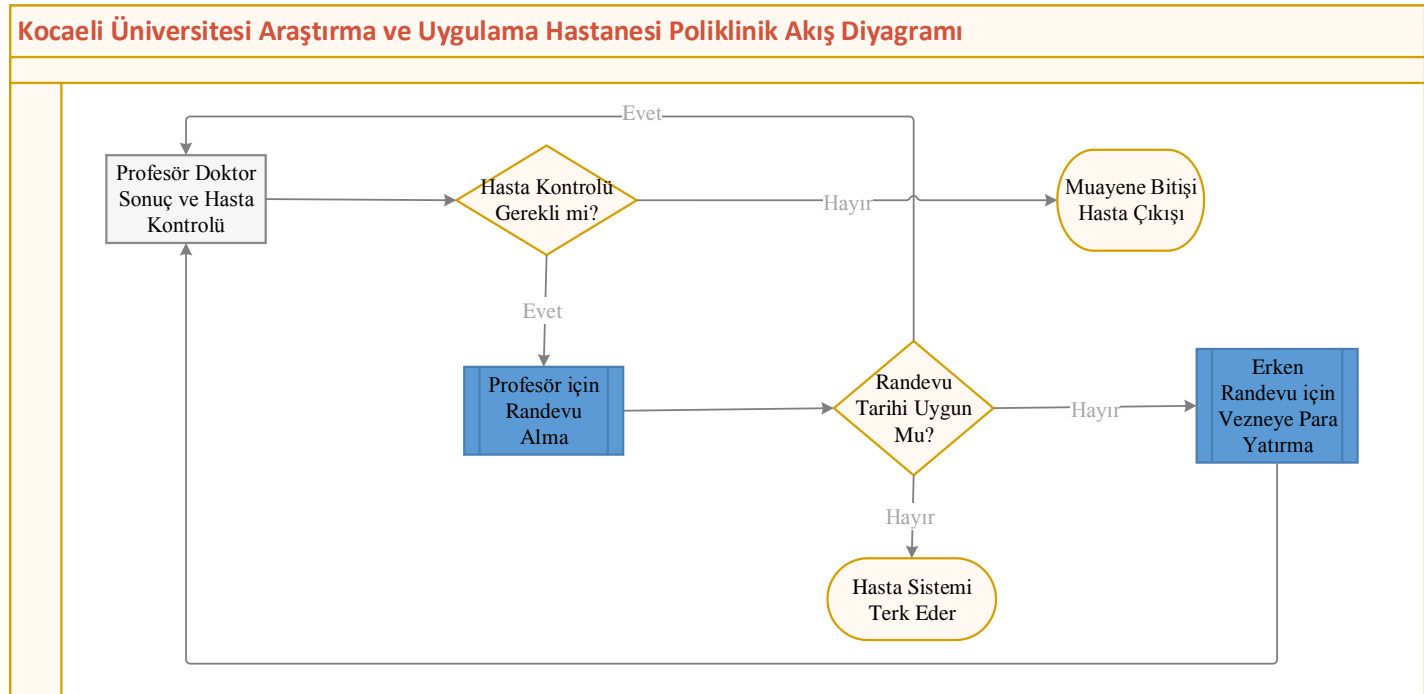

\subsection{Uygulama}

\subsubsection{Sürecin Arena Programı ile Modellenmesi}

Arena üzerinde yapılan simülasyonda hastalar randevulu ve randevusuz hastalar olmak üzere iki grupta sisteme dahil edildi. Atanan assign'lar sayesinde günlük randevusuz hastaların sisteme girişine limit koyuldu. Ayrıca randevulu hastalara öncelik verildi. Randevusuz hasta sisteme girdiği zaman, randevulu hastadan farklı olarak danışmaya gönderildi. Danışmadan sonra ise, günlük randevusuz hasta limiti dolana kadar sisteme devam eden randevusuz hastalara, limit dolduktan sonra direkt olarak çıkış verildi. Bundan sonraki aşamada randevulu ve randevusuz hastalar aynı yol üzerinde birleşerek "Hasta Kayıt" sürecine oradan da "Doktor Bekleme" process'ine dahil edildi. Atanan minimum, average ve maksimum bekleme süreleri 
ışı̆̆ında hastalar random bir şekilde "Asistan Doktor Muayenesi" sürecine iletildi. Burada atanan süreler tüm prosesler için yapılan gözlemler ve hastane dataları ışı̆ıında belirlendi. "Tetkik Gerekli Mi?" prosesinde ise yine hastane dataları kullanılarak atadığımız oran doğrultusunda hasta sistemden ayrıldı ya da tetkik aşamasına geçirildi. Asistan yönlendirmesine göre hasta "Merkez Laboratuar" ya da "Radyoloji” process'ine dahil edildi. Merkez laboratuar'ına atadığımız sub-model'ler ise hastane ziyaretleri ışı̆̆ında aşağıdaki gibi belirlendi;

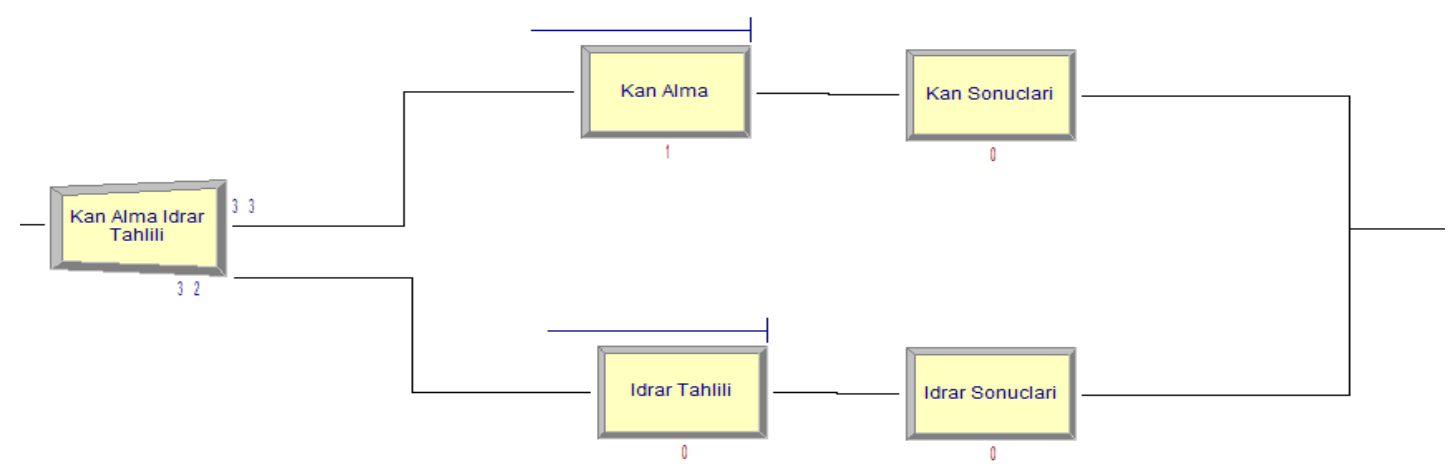

Radyoloji için belirlenen sub-model'ler ise;

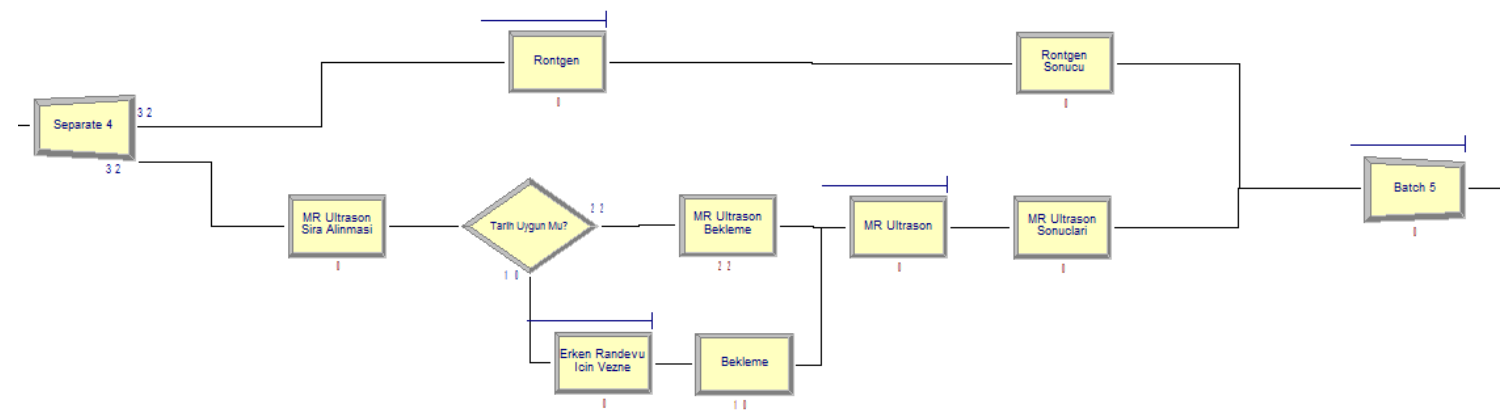

Şeklinde belirlendi. Tüm hastaların radyoloji süreçlerine dâhil edilmesini sağlamak için "separate" komutu atandı. Bu submodel içinde radyoloji süreçleri de özetlendi.

Sonuçların çıkmasından sonra "Asistan Doktor Sonuç Kontrolü"ne, ardından da "Hasta Prof. Doktora Yönlendirilecek Mi?" processlerine yönlendirildi. Hastalar, "Hasta Prof. Doktora Yönlendirilecek Mi?” process'ine atanan True komutu aracılığıyla “Prof. Dr. icin Randevu Kaydi Yaptirma" process'ine, False komutu aracılı̆̆ıyla “Hasta Cikisi 3"ına yönlendirildi. Randevu süreçleri ise aşağıda gösterildiği üzere iki farklı süreç şeklinde ilerlemektedir;

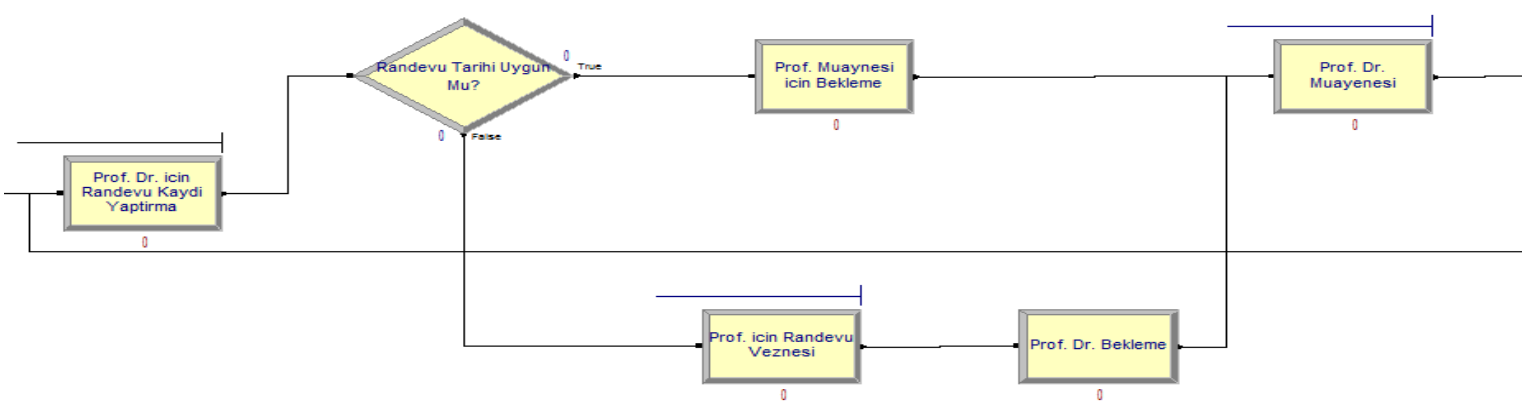


Burada "Prof. icin Randevu Veznesi" nden geçen hastalar ve diğer yoldan giden hastalar için bekleme süreleri farklı atanarak sürece bu süreler doğrultusunda dâhil edildi. "Prof. Dr. Muayenesi" process'ine gelen hastalar tekrardan tetkik isteme süreçlerine dâhil edildi. Yine True, False komutları yardımıyla hastanın çıkışı ya da sürece devam etmesi kararı "percent true" komutu aracılı̆ı̆yla oransal olarak belirlendi. Buradan sonra bir başka decide process'ine giren hastalar "Asistan Doktorun Istedigi Tetkikler Yeterli Mi?" sorusunun cevabına göre iki farklı yola yönlendirildi. False durumu hastayı "Prof. Dr. icin Tetkik ve Sonuclari"na yönlendirirken, True cevabı "Prof. Dr. Sonuc Kontrolu”ne iletmektedir. "Prof. Dr. icin Tetkik ve Sonuclari" için sub-modeller ise şu şekildedir;

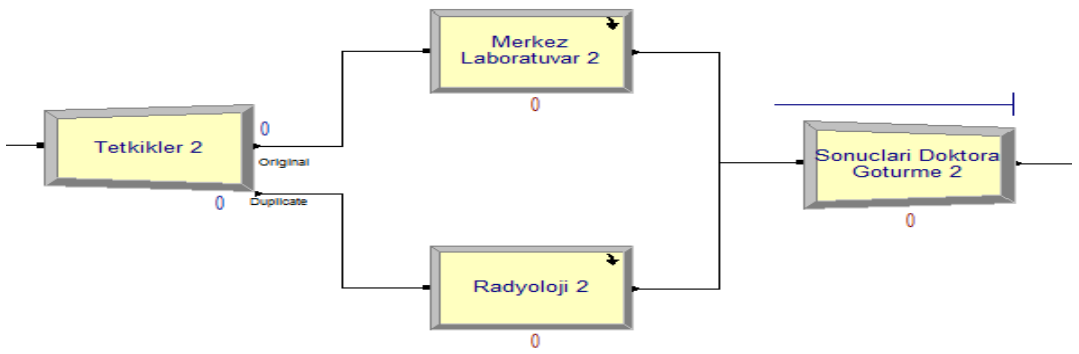

Daha önce de belirtilen Merkez Laboratuar ve Radyoloji sub-modelleri bu süreç için de atandı. Sürecin devamında ise False yönlendirmesine dâhil olan hastalar True yönlendirmesinde gelen hastalarla ortak yol olan "Prof. Dr. Sonuc Kontrolu"ne dâhil edildi. "Hasta Kontrolu Gerekli Mi?"ne gelen hastalar tekrardan bir decide procesine dâhil edilerek çıkış ya da tekrardan “Prof. Dr. icin Randevu Kaydi Yaptirma”ya gönderildi.

Yapılan araştırmalar ışığında hastaneye gelen hastaların dağılımı üssel dağılıma uygun olduğu görüldü. Belirlenen EXPO(15) komutu 15 dakikalık aralıklarla hastaların sisteme sokulduğunu temsil etmektedir. Günlük maksimum gelen randevusuz ve randevulu hasta sayıları "Max Arrivals" komutuyla belirlendi. Bu değerler hastanede yapılan gözlemler, asistan ve profesörlerle yapılan görüşmeler ve hastane verileri doğrultusunda ortalama olarak sisteme girildi.

"Action" komutu sürecin nasıl ilerleyeceğini temsil eder. "Seize Delay Release" hastanın gel-bekle-devam et akışına sokulduğu belirler. "Priority" iki veya daha çok seçeneğin olduğu durumlarda hangi process'in ilk olarak sisteme sokulacağını belirtirken, "delay type" daha önce de bahsedilen dağılımın şeklini gösterir.

Separate komutunu "Tetkikler" komutu üzerinden incelendiğinde hastanın bu process sonrasında hangi oranda bir sonraki processlere yönlendirileceğini gösterir. "Number of Dublicates" ise hastanın kaç kere bu sürece dâhil edileceğini belirtir. Batch ise toplayıcı görevi görür. Separate komutunda çıkan hastaları tekrardan birleştirir. Buradaki size, batche kaç farklı process'ten giriş olacağını gösterir.

\subsection{Sürecin Yalın Prensipler Doğrultusunda İyileștirilmesi}

Yapılan araştırmalar ve yerinde gözlemler sonucu oluşturulan Arena Simülasyonu incelendiğinde darboğazlar olduğu belirlendi. Bu boğazlara müdahale etmek için farklı senaryolar uygulandı. Bu senaryolar

Senaryo 0: Kocaeli Üniversitesi Eğitim ve Araştırma Hastanesi Genel Cerrahi Polikliniği'nin şu anki hali Arena üzerinde simüle edildi.

Senaryo 1: Hasta kayıt işleminin kaldırılması

Bu senaryo internetten randevu almanın yaygınlaşması, halkın bu konuda bilinçlendirilmesi ile hasta kayıt işleminin kaldırılması sonucu gerçekleşecek gelişmelerin incelendiği senaryodur. Numaratörlerden alınan sıra numarası ile direkt olarak doktor bekleme aşamasına dâhil edilen hastalar ile bekleme süresi ve toplam zamanın azaltılması, darboğazlardan kurtulunması amaçlandı.

Senaryo 2:Vezne işlemi QR Code koyulmuş hali

Yaygınlaşan akıllı telefonlar ve teknoloji kullanımına paralel olarak, gelen hastaların düşük bir yüzdesini etkileyecek olsa dahi -akıllı telefon ve internet bankacılığı kullanımına paralel olarak- hastane içinde vezne bölümünde oluşan yoğunluğun asgari seviyeye indirilmesi amaçlandı. 
Senaryo 3: Kayıt çalışanlarının sayısı 1 arttırılırsa sistemde oluşan beklemelerin en önemli kaynağı olan kayıt aşamasını hızlandırabilmek ve hizmet kalitesini artırmak için her kayıt masasında çalışan kişi sayısı 1 arttırıldı. Senaryo 1 ile beraber uygulandığında bu artış sadece profesör kayıt aşamasındaki çalışan sayısına uygulandı.

Senaryo 4: Verilen 3 senaryo beraber uygulanarak sonuçlar gözlemlendi.

Senaryoların çok kez uygulanması sonucu ortaya çıkan sonuçlar Çizelge 2'deki gibi gerçekleşmiştir;

Her bir senaryo için Randevulu ve Randevusuz hasta bekleme süreleri ve toplam sistemde kalma süreleri verilmiştir. Randevulu hastaların sistemde geçirdikleri süreler ve bekleme sürelerinin fazla olmasının temel sebebi hasta sayısı farkıdır. Günlük gelen randevulu hasta sayısı, randevusuzların iki katından fazla olduğundan sistemde daha çok bekliyormuş gibi bir sonuç ortaya çıkmaktadır. Bu sonuç tam olarak gerçeği yansıtmamakla beraber, sonuçlar incelenirken randevulu ve randevusuz hastayı karşılaştırmak yerine kendi kategorilerinde değerlendirmek daha sağlıklı olacaktır.

Senaryolar incelendiğinde randevulu hastaların toplam ve bekleme sürelerine en büyük etkiyi yapanın Senaryo 1 olduğu görüldü.

Randevusuz hasta bekleme süresine Senaryo 4 en büyük etkiyi yaparken, toplam süreyi Senaryo 2'nin en fazla değiştirdiği gözlemlendi.

Hasta kayıt işleminin kaldıııması ile randevulu hasta sistem sürelerine direkt etki yapılırken; vezne işlemine QR Code koyulması ve tüm senaryoların birlikte uygulanması ile randevusuz hasta süreçleri geliştirildi.

Çizelge2: Senaryoların çok kez uygulanması sonucu ortaya çıkan sürelere ilişkin sonuçlar

\begin{tabular}{|c|c|c|c|c|}
\hline & $\begin{array}{c}\text { Bekleme süresi } \\
\text { (Randevulu Hasta) }\end{array}$ & $\begin{array}{c}\text { Bekleme Süresi } \\
\text { (Randevusuz Hasta) }\end{array}$ & $\begin{array}{c}\text { Toplam Zaman } \\
\text { (Randevulu Hasta) }\end{array}$ & $\begin{array}{c}\text { Toplam Zaman } \\
\text { (Randevusuz Hasta) }\end{array}$ \\
\hline Senaryo 0 & 127.61 saat & 76,3 saat & 759.57 saat & 462.54 saat \\
\hline Senaryo 1 & 122.81 saat & 83,91 saat & 756.42 saat & 506.83 saat \\
\hline Senaryo 2 & 125.23 saat & 71,71 saat & 780.36 saat & 441,55 saat \\
\hline Senaryo 3 & 126.12 saat & 73,06 saat & 768.95 saat & 479,46 saat \\
\hline Senaryo 4 & 130,28 saat & 68,41 saat & 773,19 saat & 472,49 saat \\
\hline
\end{tabular}

\section{SONUÇ}

Bu çalışmada hastaların hastanedeki süreçlerinin uzun sürmesi konu edilmiş olup, sürecin uzamasında ve hastaların bekleme sürelerinin çok olması mevcut sistemin verimli kullanılmamasına bağlanmıştır. Kalite yöntemlerinden yalın yönetim anlayışının sadece üretim sistemlerinde değil hizmet sektöründe de uygulanabileceği konu edinilen araştırma hastanesinde gösterilmiştir. Araştırma hastanesinde yapılan çalışma ile katma değer yaratmayan operasyonların ortadan kaldırılması, hastaya sunulan hizmet kalitesinin artması ve sürecin kısalması gibi büyük faydalar sağlamaktadır.

Yalın düşünce tekniklerinin uygulanması, sisteme adapte etmek veya sistemi yalın düşünce doğrultusunda değiştirmek kolay bir iş değildir, ancak hem hasta hem hastane açısından yararları düşünüldüğünde yapılması zorunlu uygulamalardır.

Yalın düşünce ve buna bağlı yapılacaklar süreklilik arz edecek, hastane yöneticilerinden başlanarak tüm çalışanların bu sürece tabi tutulması gerekecektir. Bütün çalışanlar özellikle bizzat o işi yapan çalışanlar kendi işlerini iyileştirebilecek yalın düşüncenin olumlu sonuçlarını en başta kendileri görecektir. Bu gelişmeleri gören ve tüm hastaneye yayılması ise yöneticilere ve onların diğer çalışanları yönlendirmesi ile daha da kolaylaşacaktır.

Bu çalışmada yalın düşünce tekniklerinden değer akış haritalandırma, iş standartlaştırma ve 5 genel cerrahi polikliniği hastalarının süreçlerinde iyileşme sağlanması için kullanılmıştır. Araştırma hastanesinden alınan veriler ile hastanenin şimdiki hali ve buna bağlı geliştirilecek dört farklı öneri Arena programında benzetim haline getirilmiştir. Öneriler arasında hastaların gereksiz yere beklemesini önlemek amacı ile hasta kayıt sisteminin ortadan kaldırılması, vezne işleminin QR code ile sağlanması, kayıt çalışanlarının sayısının artırılması ve bunların hepsinin bir arada yapıldığıdır.

Randevusuz hastaların danışmadaki numaratörden aldığı numara ile hasta kayıtta bir sıraya girmesi ve randevulu hastaların ise geliş saatleri belli olmasına rağmen tekrar gereksiz yere hasta kayıtta kayıt yaptırması bekleme süresini ciddi oranda arttırmaktadır. Numaratörde TC kimlik numarası ve gidilecek olan doktorun seçilmesi ile hasta kayıtta yapılan işleme gerek 
kalmayacak ve hasta kayıt kaldırılabilecektir. Bu sayede hastaların bekleme süresi azaltılırken hasta kayıtta çalışanlar farklı departmanlara aktarılabilir. Vezne işleminin gelişen teknoloji ile QR code kullanılarak telefonlardan ödeme yapılması sağlanabilir bu sayede hem bekleme hem işlem süresi kısaltılır hem de çalışan maliyeti düşürülebilir. Kayıt çalışanları birden fazla iş yapmakla sorumlu tutulduğu için asıl işlerini gecikmeli yapmakta bu da süreci uzatmaktadır ancak çalışan sayısının artırılması sürecin kısalmasına ve hastaların daha az beklemesini sağlayacaktır.

Bu dört farklı iyileşme önerisinde de hastaların bekleme sürelerinde düşüş gerçekleşmiş olup çalışan sayısında azalma sağlayan öneriler de maliyetin düşmesini sağlamıştır. Hastane yöneticileri kendilerine uygun buldukları, uygulayabileceklerini düşündükleri öneri ve önerileri uygulamaya koyarak hastaların sistem içinde daha az beklemesini sağlayarak kalite artımında bulunabilirler.

\section{KAYNAKLAR}

Anderson, D. R., Sweeney, J. D., Thomas, A. W., (2000), “An Introduction to Management Science Quantitative Approaches to Decision Making", Sout - Western College Publising.

Artışık, O. (2015). Yalın Lojistik Ve Bir 3pl Şirketinde Değer Akışı Analizi (Doctoral dissertation, Fen Bilimleri Enstitüsü).

Bahensky, J.A., Roe, J., Bolton, R., (2005). Lean Sigma-Will It Work for Healthcare? Journal of Healthcare Information Management.

Dickson, E. W., Sıngh, S., Cheung, D. S., Wyatt, C. C., Nugent, A. S. (2009). Application of Lean Manufacturing Tecniques in the Emergency Department, The Journal of Emergency Medicine, 37 (2), 177-182.

Dickson, E. W., Anguelov, Z., Vetterıck, D., Eller, A., Sıngh, S. (2009). Use of Lean in the Emergency Department: A Case Series of 4 Hospitals, American College of Emergency Physicians, 54 (4), 504-510.

Fliehman D.G., Auld D.D. (1993). “Customer Retention Througt Quality Leadership”, The boxter approach.

Hagg, H., Workman-German, J., (2007), "Implementing Lean Six Sigma Methodologies in the Radiology Department of A Hospital”, RCHE Publications, 27.

Harrell, C., Ghols, Biman, K., Bowden, R. (2000). Simulation using promodel, Hill Companies, Inc, America.

Kumar, C. S., \& Panneerselvam, R. (2007). Literature review of JIT-KANBAN system. The International Journal of Advanced Manufacturing Technology,32(3-4), 393-408.

Langabeer, J. R., Dellıfraıne, J. L., HEINEKE, J., ABBASS, I. (2009). Implementation of Lean and Six Sigma quality initiatives in hospitals: A goal theoretic perspective, Springer Science, 9 (21), 1-15.

Marshall L., Hagood C., Royer A., Reece C., Maloney S. (2006). Using lean methods to improve OR turnover times, Association of Operating Room Nurses. AORN Journal.

Naraghi, A. M. and Ravipati, U. P., (2009). “Lean Healthcare in the Emergency Ward of Sahlgrenska"

Özyörük, B., Kütük, D., “İş Ortamını Yeniden Düzenlemenin İş Verimliliğine Etkileri”, Ergoterapi ve Rehabilitasyon 2014 Mayıs; 2, 2: 74-75.

Rexhepi, L. and Shrestha, P., (2011). "Lean Service Implementation in Hospital: A Case study conducted in University Clinical Centre of Kosovo, Rheumatology department".

Shazali, N. A., Habidin, N.F., Ali, N., Khaidir, N. A. \& Jamaludin, N. H. (2013) "Lean Healthcare Practice and Healthcare Performance in Malaysian Healthcare Industry" International Journal of Scientific and Research Publications, Malay.

Sur H., "Sağlığın ve Sağlık Hizmetlerinin Planlanması", SAYED Sağlık Yönetimi ve Eğitimi Dergisi, Yıl 1, Sayı 2, Mayıs 2008.

Tikici, M., \& Derin, A. (2006). TOPLAM KALITE YÖNETIMININ RADIKAL UNSURLARINDAN BIRISi OLARAK YALIN YÖNETIM. Elektronik SOSYal Bilimler Dergisi, 15(15).

Yalçın, M., (2008), [Acil Servis Hizmetlerinin Simülasyonu: Karşıyaka Devlet Hastanesi Uygulaması], ss. 45-102.

"Yalın Hastane Sistemleri ve Uygulamaları Projesi", Özellikli Sağıı Hizmetleri ve Proje Daire Başkanlığı, erişim 5 Haziran, 2015. http://www.tkhk.gov.tr/DB/8/2946_yalin-hastane-sistem.

Yıldız, S., [Benzetim Modellemesi İle Üretim Sistemlerinde Süreç Optimizasyonu Ve Bir Uygulama Çalışması], ss. 34-35.

Yıldız, S., Yalman, A. G. F. (2015). Sağlık İşletmelerinde Yalın Uygulamalar Üzerine Genel Bir Literatür Taraması. Uluslararası Sağlık Yönetimi ve Stratejileri Araştırma Dergisi, 1(1).

Zerenler, M., \& İraz, R. (2006). Japon yönetim anlayışı ve şirket ağları (keiretsu) analizi. Selçuk Üniversitesi Sosyal Bilimler Enstitüsü Dergisi, $16,757-776$ 